\title{
Physicochemical characteristics and sensorial properties of dry noodle supplemented with unripe banana flour
}

\author{
${ }^{1 *}$ Anggraeni, R. and ${ }^{2}$ Saputra, D. \\ ${ }^{1}$ Department of Food Technology, Sahid University, Jakarta 12870, Indonesia \\ ${ }^{2}$ Department of Food Technology, Binus University, Tangerang 15326, Indonesia
}

Article history:

Received: 26 December 2017

Received in revised form: 2

February 2018

Accepted: 3 February 2018

Available Online: 16

February 2018

Keywords:

Fiber,

Dry Noodles,

Unripe Banana flour,

Physical-chemistry,

Sensory evaluation

DOI:

https://doi.org/10.26656/fr.2017.2(3).061

\begin{abstract}
Banana is a type of fruit that grows in tropical and sub-tropical areas such as Indonesia, Malaysia, Africa (Madagascar), South America and also central America. Indonesia itself is the largest banana producing country in Asia because $50 \%$ of the production of banana Asia is produced by Indonesia. This fruit is consumed in the form of fresh (fresh fruit) because it tastes good. In addition, bananas can be processed into banana chips and banana butter, but still, a few who processed it into another durable product. Banana flour has been processed into various types of food, including made into bread, baby food, pancakes, pastries, dry noodles, and pasta. This study aimed to utilize unripe bananas into dried noodle food products and evaluate their chemical, physical and sensory contents. This research was divided into 4 stages, namely the production of banana flour, the characterization of banana flour, the manufacture of dry noodle substitution of banana flour and the characterization and sensory analysis of banana flour substitution noodles. The results showed that unripe banana flour contains $12.91 \%$ moisture content, $0.46 \%$ fat content, $1.02 \%$ ash content, $4.45 \%$ protein content $4.45 \%$, $81.15 \%$ carbohydrate content and $2.75 \%$ food fiber (dry basis). The resulting unripe banana flour was then applied as a substance of flour substitution in the manufacture of noodles. The results showed that noodles that had the same acceptance as control were noodles containing $10 \%$ and $30 \%$ unripe banana flour.
\end{abstract}

\section{Introduction}

Banana flour can be made from bananas that are cooked or still raw. Banana flour has been processed into various types of food, including made into bread, baby food, pancakes, pastries, dry noodles, and pasta. Unripe bananas are a good source of carbohydrates and nutritionally interesting bioactive compounds. Several studies have suggested that consumption of unripe bananas exerts a beneficial effect on human health, associated with the indigestible components.

Nowadays bananas are being considered as a food ingredient (Ovando-Martinez et al., 2009). According to the literature, green bananas are very rich in the resistant starch type 2 (RS2) from 52.7 to $54.2 \mathrm{~g} / 100 \mathrm{~g}$ (Tribess et al., 2009).

Based on data from BPS (2011), it is known that instant noodles have the highest share of expenditure after flour followed by instant food noodles. Noodle products are a staple food in many parts of Asia. The development of new products is a strategic area of the food industry. Traditional noodles are claimed to lack other essential nutritional components such as dietary fiber, vitamins, minerals, and bioactive compound. Thus, noodle products are suitable for enhancing health after incorporating sources of fiber and essential nutrients (Choo and Aziz, 2010).

Some research has been recently carried out to improve the nutritional properties of food products adding to its supplements from unripe banana flour. Choo and Aziz (2010) reported that green banana flour has potential as a source of fiber when substituted in yellow alkaline noodle products. Ovando-Martinez et al. (2009) reported that pasta products containing banana flour exhibit a low rate of carbohydrate enzymatic hydrolysis and they could help broaden the range of lowglycemic index foods available to consumers. However, there is no information on the use of unripe banana flour in dried noodle making. Therefore, this study is aimed to utilize bananas into dried noodle food products and evaluate their chemical, physical and sensory contents. 


\section{Materials and methods}

\subsection{Materials}

The main ingredients used were Nangka Banana (Musa sp L) obtained from the market around of Bogor, West Java. Materials for analysis werePotassium sulfate $\left(\mathrm{K}_{2} \mathrm{SO}_{4}\right)$, Kjeltabs, Sulfuric acid $\left(\mathrm{H}_{2} \mathrm{SO}_{4}\right)$, Hydrogen peroxide $\left(\mathrm{H}_{2} \mathrm{O}_{2}\right)$, Boric acid $\left(\mathrm{H}_{3} \mathrm{BO}_{3}\right)$, Indicator bromocresol green, methyl red, Sodium hydroxide $(\mathrm{NaOH})$, Sodium thiosulfate $\left(\mathrm{Na}_{2} \mathrm{~S}_{2} \mathrm{O}_{3}\right)$, Hydrogen Chloride $(\mathrm{HCl})$, Hexane $\left(\mathrm{C}_{6} \mathrm{H}_{14}\right)$, Sodium metabisulfite $\left(\mathrm{Na}_{2} \mathrm{~S}_{2} \mathrm{O}_{5}\right)$, Sodium bicarbonate $\left(\mathrm{NaHCO}_{3}\right)$, Sodium chloride $(\mathrm{NaCl})$,Sodium tripolyphosphate $\left(\mathrm{Na}_{5} \mathrm{P}_{3} \mathrm{O}_{10}\right)$, Carboxymethylcellulose (CMC). While the equipment used included slicer tool (slicer), tray dryer, siege and sieve tools, oven, steam, noodle printing machine and other standard equipment glass for Chemical analysis.

\subsection{Unripe banana flour preparation}

Banana flour was made from old but unripe bananas. The degree of aging chosen was based on the rate at which the maximum piercing content was. Bananas are removed from the sides, washed and steamed or boiled for 10-15 minutes. This steaming or boiling will facilitate stripping, reducing or removing sap, and improving the banana flour and the resulting flour.After peeling, the fruit was sliced thinly or bristling $(0.25-0.75 \mathrm{~cm})$ thickness and soaked in sodium metabisulfite solution (can be purchased at chemical stores) $2000 \mathrm{ppm}$ for 5 - 10 minutes. Then, the banana slices were drained and dried at $60-75^{\circ} \mathrm{C}$ for $6-8$ hours. To make flour, dried banana with a grinder, then sifted and packed in plastic bags. Banana flour ready to be processed into various food.

\subsection{Unripe banana dried noodle processing}

Preparation of noodle product was done by using composite flour with a composition of raw banana flour by $0,10,20,30,40$ and $50 \%$. $500 \mathrm{~g}$ of composite flour, plus $2.5 \mathrm{~g}$ of guar gum, $5 \mathrm{~g}$ of salt, $0.5 \mathrm{~g}$ of sodium bicarbonate, $2 \mathrm{~g}$ of Sodium tripolyphosphate (STPP) and $200 \mathrm{~mL}$ of water and then mixed and stirred until smooth. The dough was then allowed to stand for 10 minutes. The dough was then made into the sheets (sheeting) with a thickness of $1.6 \mathrm{~mm}$ and the cut. The cut noodle was steamed for 10 minutes in a vaporizer at $100^{\circ} \mathrm{C}$ and then dried for 5 hours at $50^{\circ} \mathrm{C}$ and then packed. Preference test was done on the noodles produced to determine the best formula.

\subsection{Optimum cooking time analysis}

The principle of this analysis is to measure the time until the noodles do not form a white line when pressed with two glass pieces. Dry noodles were weighed $5 \mathrm{~g}$, then $150 \mathrm{~mL}$ of water was boiled on a cup of the covered cup and allowed to boil for 3 minutes. The noodle sample was inserted into the cupping glass and closed again. The stopwatch was switched on just as the sample is put in boiled water. Every minute a noodle strand is taken and pressed with two glasses. Cooking was said to be optimum when no white lines are formed when noodles are pressed with two glass pieces (Chillo et al., 2008).

\subsection{Preference Test}

The noodle product tested was a rehydrated noodle product using the optimum cooking time that has been analyzed. To know the level of panelist's preference, a multivariate analysis of preference test results was performed. If based on the multivariate analysis, it is stated that there is the real influence on treatment then it will be continued with Duncan's advanced test.

The preference test used at this stage was a hedonic test. Panelists used were untrained panelists as many as 36 panelists. The scoring scores used in this test were 7 levels, score 1 (strongly dislikes), 2 (dislikes), 3 (slightly dislikes), 4 (neutral), 5 (rather like), 6 (like) And 7 (very like). Preferred rate assessment was based on product characteristics including stickiness, elasticity, taste and overall.

Samples analyzed using sample code as follows: 357 ( $0 \%$ unripe banana flour); 631 (10\% unripe banana flour); 753 (20\% unripe banana flour); 289 (30\% unripe banana flour); 546 (40\% unripe banana flour) and 131 ( $50 \%$ unripe banana flour)

\subsection{Chemical analysis}

Analysis of water content, ash content, protein and fat content were conducted based on AOAC (2000) while carbohydrate analysis was analyzed by the difference.

\subsection{Solid loss analysis during cooking}

The solid loss during cooking (SL) was measured based on the weight loss of noodles after cooking noodles at a cooking time in accordance with optimum cooking time so that the unit of SL is the percentage by weight of noodles lost during cooking. The percentage by weight of noodles lost during the cooking was considered as the amount of solid that comes out during cooking (SL). $5 \mathrm{~g}$ of dried noodle sample was soaked in $150 \mathrm{ml}$ of boiled water (for 4 minutes) to reach the optimum time of cooking, then noodles sprinkled with $50 \mathrm{ml}$ cold water (2 times) to stop the heating and dissolve the solids on the surface of the noodles. Noodles were drained for 5 minutes and then weighed. Water 
used for cooking and then dried at $105^{\circ} \mathrm{C}$ until it reached a weight constant (AACC, 1999).

Solid loss (\%) $=\frac{\text { Dried supernatant }}{\text { Initial weight }} \times 100 \%$

Water Absorption $=\frac{\text { Weight of cooked drained noodle }- \text { weight of raw noodle }}{\text { Weight of raw noodle }} \times 100 \%$

\subsection{Statistical analysis}

The experimental results were analyzed using SPSS software 20.0. Data were expressed as the mean \pm standard deviation of duplicate analysis. A one-way analysis of variance (ANOVA) at the 5\% significance level was used to determine significant differences $(P<$ 0.05 ) between means.

\section{Results and discussion}

\subsection{Chemical composition of unripe banana flour and} wheat flour

Banana flour is one way of preserving bananas through processing. The processing of banana into banana flour has several advantages: longer shelf life, easily processed into food, can be formulated into several forms of processed cake, and it is easy to digest so safe for consumption of elderly and children (baby). Banana flour is the result of grinding dried banana (gaple banana). Basically, all types of bananas can be processed into banana flour. However, different types of bananas will produce different characteristics. Bananas that can be used as raw materials of banana flour are bananas that are old but not yet ripe and contain high levels of flour (low sugar content). According to Murtiningsih and Imam (1988), the best type of banana used to make banana flour was a kind of kapok banana.

In this study, nangka banana was used. This is because kapok banana has a higher economic value compared with nangka banana. In addition, according to Murtiningsih and Imam (1988), it was known that acid levels in kapok bananas were higher compared with nangka banana i.e. $1.85 \%$ and $0.85 \%$ respectively. High

Table 1. Comparison of proximate data of raw banana flour with wheat flour

\begin{tabular}{clcc}
\hline No. & \multicolumn{1}{c}{$\begin{array}{c}\text { Chemical } \\
\text { Composition (\%) }\end{array}$} & $\begin{array}{c}\text { Unripe } \\
\text { banana flour }\end{array}$ & Wheat flour \\
\hline 1. & Water content & 12.91 & $14: 00^{\mathrm{a}}$ \\
2. & Ash content & 1.02 & $0: 58^{\mathrm{a}}$ \\
3. & Fat content & 0.46 & $1: 16^{\mathrm{a}}$ \\
4. & Protein content & 4.45 & $13.95^{\mathrm{a}}$ \\
5. & Carbohydrate content & 81.15 & $79.36^{\mathrm{a}}$ \\
6. & Food fiber & 2.75 & $4.95^{\mathrm{b}}$ \\
\hline
\end{tabular}

Values are shown as mean $(\mathrm{n}=3)$. All data measured in dry base

${ }^{\mathrm{a}}$ Figoni (2003); ${ }^{\mathrm{b}}$ Gustiar (2009), levels of acid in banana kapok feared will affect the taste of noodle products to be produced.

The results showed that raw banana flour had a water content of $12.91 \%$ (Table 1). The water content of raw banana flour is still in the good range of moisture content according to Moorthy (2002), where the water content ranged from $6-16 \%$. High water content is not desirable because it will cause the flour to become moist and encourage the growth of food spoilage and pathogenic microorganisms.

Table 1 shows that unripe banana flour has ash content was about $1.02 \%$. This value was much higher when compared with ash content in wheat flour which was in the range of $0.5 \%$. Ash consists of inorganic materials and mineral salts (Figoni, 2003). According to Beynum and Roels (1985), the ash in starch consists of components of phosphorus, sodium, potassium, magnesium, and calcium.

The fat content of raw banana flour was $0.46 \%$. This value was lower when compared with the level of fat in wheat flour which amounted to $1.16 \%$. This condition can be due to the fact that the fats naturally bind to the bulb starch granules are much smaller when compared to the fat that binds to the cereal starch granules. (Fenema, 1996).This is also likely to cause low-fat content in raw banana flour compared to wheat flour and cornstarch.

Raw banana flour had a protein content of $4.45 \%$. This value was much lower when compared with protein content in wheat flour, which amounted to $13.95 \%$.

\subsection{The optimum cooking time}

The optimum cooking time is the time required for the noodles to reabsorb water so that the texture becomes elastic as before it is dried.The result of the optimum cooking time analysis shows that all raw dried noodle supplemented with unripe banana flour samples ranged from 2 to 4 minutes (Table 2). The optimum time of cooking is influenced by several factors, example the thickness of the noodle strands (Huang and Lai, 2010) and also the gelatinized temperature of the starch used (Yadav et al., 2011). The optimum cooking time obtained is then used for cooking unripe banana noodle for preference test.

Table 2. Effect of raw banana flour content on cooking time (min) of noodles

\begin{tabular}{cc}
\hline Unripe banana flour (\%) & Cooking time (minutes) \\
\hline 0 & 4.0 \\
10 & 4.0 \\
20 & 4.0 \\
30 & 3.0 \\
40 & 3.0 \\
50 & 2.0 \\
\hline () 2018 The Authors. Published by Rynnye Lyan Resources
\end{tabular}




\subsection{Preference test}

All dried noodles samples from unripe banana flour were selected from optimal formula prepared to be analyzed by the consumers in a Laboratory of Food Processing Technology. About 36 panelists with no trained experience in the preference test were recruited from Bina Nusantara University.

The sensory characteristics of a food product depend on the consumer's judgment on the choice of food. There are several parameters of consumer ratings on the quality of a food product that is assessed through sensing techniques example sensory evaluation. These parameters are color, aroma, appearance, taste, elasticity and overall assessment of the quality of food products. The main factor of consumer acceptance of a food product is very dependent on the appearance, flavor, and texture of the product. Because ultimately the target is consumer acceptance, then the sensory evaluation is the approach that is considered the most practical and cheaper cost in determining the level of consumer preference.

In this study, noodle products are produced from the main raw material of banana flour. Since the raw material used in the product is not commonly known by the community, the evaluation of sensory parameter of unripe banana noodle by the consumer needs to be done such as the color parameter of noodle, the elasticity level of noodles, the taste of noodles, the aroma, the stickiness and the overall consumer rating.

\subsubsection{Elasticity}

The results of preference test on the elasticity parameters of banana flour noodles range from 3.56-5.00 on average (Figure 1). The acceptability mean value of sensory analysis of samples from the largest in sequence for this parameter was codes 753 (20\% unripe banana flour, 4 min cooking time), 289 (30\% unripe banana flour, 4 min cooking time), 631(10\% unripe banana flour, 4 min cooking time), 546 (40\% unripe banana flour, 3 min cooking time), 357 ( $0 \%$ unripe banana flour, 4 min cooking time) and 131 (50\% unripe banana flour, 3 min cooking time),

The average range of acceptability values of the panelists tends to be low, it is assumed that the type of flour used has a low gluten content so that the level of elasticity of the dough banana flour noodle will decrease.

The results obtained in this study are similar to Rosida et al. (2013) reported that the panelist's preference level for viscosity parameter canna-flour noodle tends to be lower, it is made possible due to the composition of which is owned by the flour gluten canna lower when compared to starch.

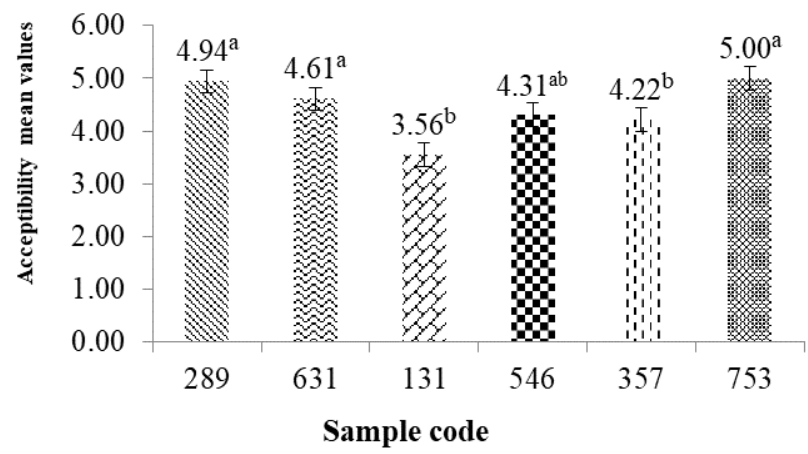

Figure 1. Effect of banana flour on elasticity optimally cooked noodles supplemented with unripe banana flour. 357 ( $0 \%$ unripe banana flour); 631 (10\% unripe banana flour); 753 (20\% unripe banana flour); 289 (30\% unripe banana flour); 546 (40\% unripe banana flour) and 131 (50\% unripe banana flour). Superscript different numbers on the graph show significantly different at the real level $\alpha=0.0$. The vertical bars on each column indicate the standard deviation.

\subsubsection{Adhesiveness}

The results of preference test of product viscosity parameter showed a significant difference ( $p$-value $\alpha=$ 0.05 ), for the noodle code 546 ( $40 \%$ unripe banana flour) with other formulations. Based on the results of panelist evaluation of unripe banana flour noodle, sample code 357 (0\% unripe banana flour) has an average acceptability score of $4.94 \pm 1.67$. The treatment that had the lowest score for the hedonic test against the stickiness of noodle is in the treatment of code $546(40 \%$ unripe banana flour) with an acceptability average score of $3.75 \pm 1.46$ (Figure 2).

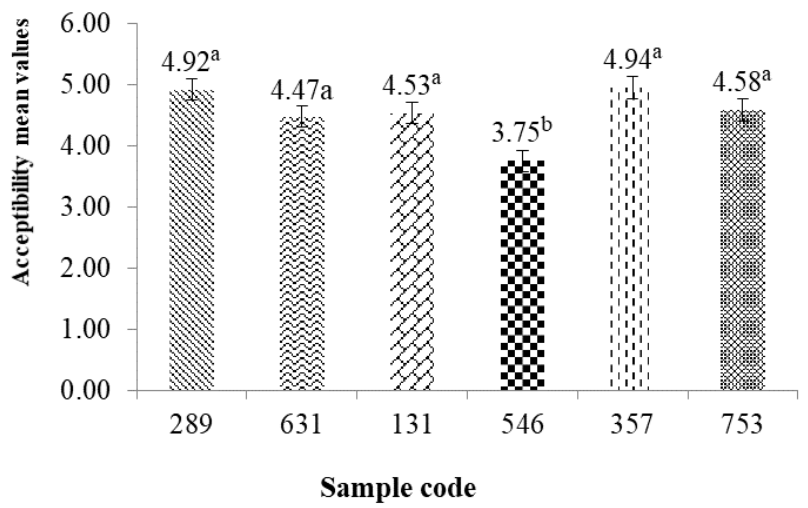

Figure 2. Effect of banana flour on adhesiveness optimally cooked noodles supplemented with unripe banana flour. 357 ( $0 \%$ unripe banana flour); 631 (10\% unripe banana flour); 753 (20\% unripe banana flour); 289 (30\% unripe banana flour); 546 (40\% unripe banana flour) and 131 (50\% unripe banana flour). Superscript different numbers on the graph show significantly different at the real level $\alpha=0.0$. The vertical bars on each column indicate the standard deviation.

The results obtained in this study are similar to those reported by Lestari and Susilawati (2015) where the 
noodle formulated with taro being flour has a median hedonic range in the range of 4.12-5.80. The stickiness of noodles is strongly influenced by gluten levels, the higher the gluten content the dough tends to be more sticky.

Widyaningsih and Murtini (2006), reported that gluten content is a protein contained in flour, is elastic in that it affects the elasticity and texture of noodles produced. Wheat or wheat proteins have special properties because they can produce a dough that can hold gas and expands elastically when the gas expands at the time of the combustion process.

This is due to the hydrated and expanding gluten properties when the flour is mixed with water. The process takes place when the dough is stirred and finally form a three-dimensional mass of gluten protein that has an elastic viscosity (Winarno, 1997).

The level of stickiness noodles has a good perception of the panelists also reported by Zhou et al. (2013), where the increased levels of konjac glucomannan on noodles, it will enhance the perception of sensory panelists against the grain and cause noodles becomes too sticky (Zhou et al., 2013).

\subsubsection{Color}

A product will have a consumer value through the color sensor parameter. The color is a visualization of a product directly visible first when compared with other parameters. Visual displays of color factors will appear first and often determine the value of a product (Winarno, 2002). The result of the color hedonic test score shows that the percentage of favorite level of 36 panelists on the color of banana flour noodle is relatively varied (Figure 3).

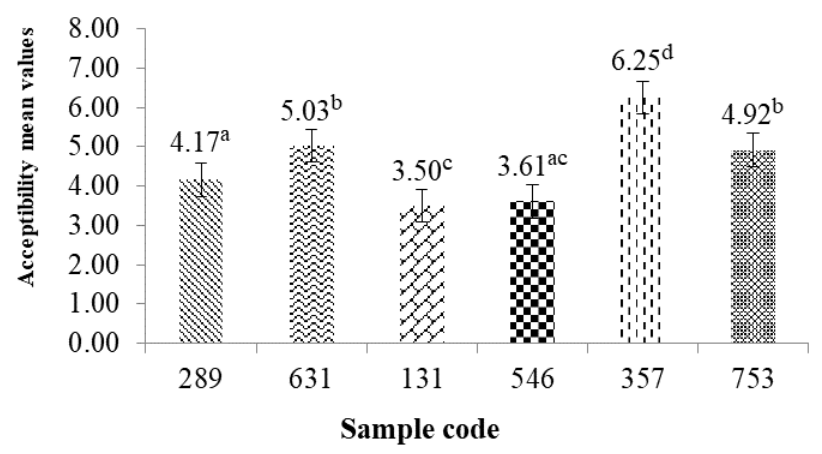

Figure 3. Effect of banana flour on color optimally cooked noodles supplemented with unripe banana flour. $357(0 \%$ unripe banana flour); 631 (10\% unripe banana flour); 753 ( $20 \%$ unripe banana flour); 289 ( $30 \%$ unripe banana flour); 546 (40\% unripe banana flour) and 131 (50\% unripe banana flour). Superscript different numbers on the graph show significantly different at the real level $\alpha=0.0$. The vertical bars on each column indicate the standard deviation.
The highest acceptability color scores are given by the panelists, namely the treatment of banana flour 357 ( $0 \%$ unripe banana flour) code significantly different and significantly different ( $p$-value $\alpha=0.05$ ) in the other treatments ie, with an average score of $6.25 \pm 1.05$. The panelist's impression of color on other treatments is varied with an average score ranging from $3.50 \pm 1.11$ to $5.03 \pm 1.38$.

Banana flour noodle code 357 ( $0 \%$ unripe banana flour) showed the highest average score. Its indicates that panelist is suspected of liking or very like the color of this formula. The high average score on the code noodle 357 indicates that the browning in the process of making noodles can be controlled well.

The results obtained in this study had an average of better color when compared to Widaningrum et al. (2005) with a value of 2.5 - 3.4. This is allegedly influenced by the type of raw material used has a high sugar content so that during the process of noodle making occurs browning reaction.

Lestari and Susilawati (2015) reported that the color of taro noodles have the acceptability value ranged from 3.28 - 6.00. The average value of panelists on flour noodles products is in accordance with the results of this study. Purwandari et al. (2014), also reported the same thing with this study, where the average result of panelist judgment on Konjac-based noodles has hedonic values ranging from $3.95-6.40$.

Other results are also presented by Omeire et al. (2015), the average panelist hedonic judgment of color parameters is particularly favored by panelists with a higher value range of $5.25-8.70$. The color is one of the main response variables that regulate food acceptance (Maga, 1989) because color depends on the sense of sight, the color of the noodles is one of the outstanding parameters in panelist decisions.

\subsubsection{Aroma}

Based on the results of the panelist assessment on the aroma parameters of unripe banana flour noodles, it is preferable that the panel on all treatment combinations ranges from $3.69 \pm 1.17-5.03 \pm 1.18$. This is suspected because banana flour has a distinctive aroma as a raw material Hulme (1981). The banana fragrance component is iso-amyl acetate, amyl acetate, amyl propionate, amyl butyrate, hexyl acetate, methyl acetate, pentanol, butyl alcohol, amyl alcohol, and hexyls alcohol. The results of the data analysis are based on a further test Duncan, showed that the addition of banana flour and water do not give a real impact on the aroma of banana flour noodles $(p$-value $=0.05)$. Figure 4 shows average panelist preferences on the aroma of banana 
flour noodles.

The results obtained in this study had an average of preferred aroma panelists, compared with Widaningrum et al. (2005), i.e. with an acceptability average value of 1.3 - 1.6. Lestari and Susilawati (2015), reported that the flavor of taro bench flour noodle products ranged from $4.12-4.80$ hose. The average value of the preference test is not much different from that reported by Lestari and Susilawati (2015).

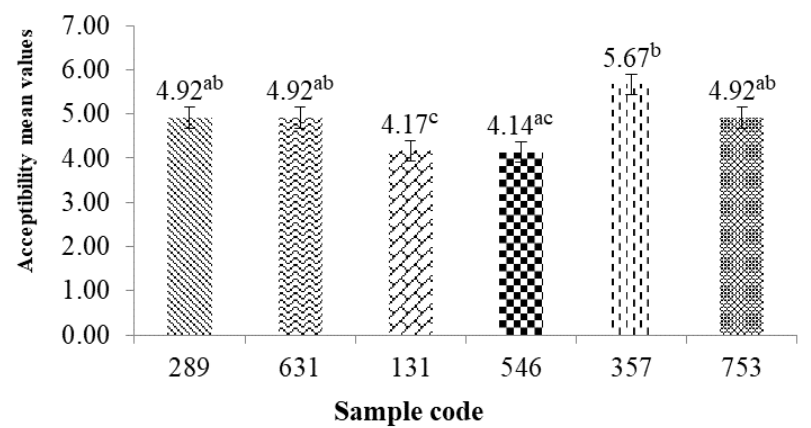

Figure 4. Effect of banana flour on aroma optimally cooked noodles supplemented with unripe banana flour. $357(0 \%$ unripe banana flour); 631 (10\% unripe banana flour); 753 (20\% unripe banana flour); 289 (30\% unripe banana flour); 546 (40\% unripe banana flour) and 131 (50\% unripe banana flour). Superscript different numbers on the graph show significantly different at the real level $\alpha=0.0$. The vertical bars on each column indicate the standard deviation.

\subsubsection{Flavors}

Based on the measurement of the hedonic value of banana flour noodles, it can be seen that the average of panelist's preference for unripe banana flour noodles flavor is relatively varied in all experimental formulations. The noodle formulation of code $357(0 \%$ unripe banana flour) is the preferred formulation by panelists with an acceptability value of $5.67 \pm 1.07$, while the lowest has an acceptability value of $4.14 \pm 1.40$ i.e. the sample code 546 ( $40 \%$ unripe banana flour). The results of the data analysis are based on a further test Duncan, showed that the addition of banana flour and water give a real impact on the taste of banana flour noodles ( $p$-value $\alpha=0.05$ ). The average graph of panelist's preference for unripe banana flour noodles can be seen in Figure 5.

Based on the results obtained in this study it is seen that unripe banana flour noodles tend to be favored by panelists to taste parameters. Purwandari et al. (2014), reported that the panelist's preference level of noodlebased unripe banana flour has hedonic values ranging from 3.23 - 5.00 hose. Unlike the case with Lestari and Susilawati (2015), who reported that the color of the product taro beneng flour noodle ranges in the interval
3.28-6.00. The average value of panelists on flour noodles products is in accordance with the results of this study. Purwandari et al. (2014), also reported the same thing with this study, where the average result of panelist judgment on Konjac-based noodles has hedonic values ranging from 3.95-6.40.

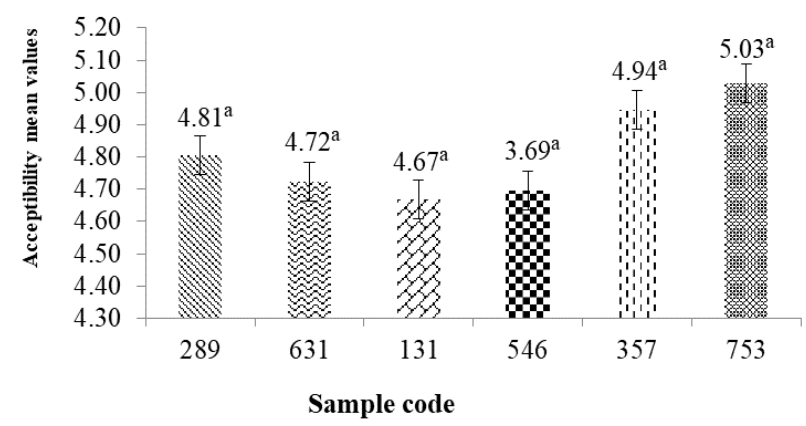

Figure 5. Effect of banana flour on flavors optimally cooked noodles supplemented with unripe banana flour. $357(0 \%$ unripe banana flour); 631 (10\% unripe banana flour); 753 (20\% unripe banana flour); 289 (30\% unripe banana flour); 546 (40\% unripe banana flour) and 131 (50\% unripe banana flour). Superscript different numbers on the graph show significantly different at the real level $\alpha=0.0$. The vertical bars on each column indicate the standard deviation.

Omeire et al. (2015), reported that the average panelist hedonic judgment of taste parameters is particularly preferred to a higher value range of 6.25 8.30. Zhou et al. (2013), explains that the level of panelist preference for aroma and taste parameters of conjunctive noodles is not influenced by raw materials alone, however, the interaction of the two factors in the preparation method and raw materials significantly affects the color parameters, the taste of the mouth, and the overall preference.

\subsection{Chemical composition of raw dried noodle supplemented with unripe banana flour}

Based on the acceptability average value of preference test, it was known that noodle products with a concentration of raw banana flour by $10 \%$ and $30 \%$ have the same acceptance as wheat flour noodles (control). The results showed that water content of banana flour substitution noodles that had the same consumer acceptance was in the range of $9 \%$ (Table 3). The water content of the raw materials used will affect the instant noodle water content produced. The water content decreasingly significant when the level of unripe banana flour in the noodles increased. Based on OvandoMartinez et al. (2009), on the study report that this pattern was related to the decrease of the protein content with the increase in the amount of banana flour in the noodles where the network produced by the gluten is reduced; consequently, the separation of water during the drying is higher. Pacheco-Delahaye (2001) and 
Ritthiruangdej et al. (2011) also reported the same results in which the addition of banana flour decreases the moisture content of the resulting paste product.

Table 3. Chemical composition of raw dried noodle supplemented with unripe banana flour

\begin{tabular}{lccc}
\hline $\begin{array}{c}\text { Chemical } \\
\text { Composition (\%) }\end{array}$ & Control & $\begin{array}{c}10 \% \text { unripe } \\
\text { banana flour }\end{array}$ & $\begin{array}{c}30 \% \text { unripe } \\
\text { banana flour }\end{array}$ \\
\hline Water content & 9.76 & 9.81 & 9.48 \\
Fat content & 0.44 & 0.43 & 0.45 \\
Protein content & 13.13 & 14.03 & 15.73 \\
Ash content & 1.71 & 1.72 & 2.17 \\
Carbohydrate & 74.95 & 74.01 & 72.16 \\
Dietary fiber & 1.36 & 1.45 & 2.84 \\
\hline
\end{tabular}

Values are shown as mean $(n=3)$. All data measured in dry base

Sudarmadji (1997) stated that water is an important component in food because it will affect the appearance, texture, and taste of food will also affect the shelf life of the product.

The fat content of noodles product did not change significantly with the addition of raw banana flour. This result is in line with Ritthiruangdej et al. (2011). This is because of the low fat content of raw banana flour compared to wheat flour (Table 1). In addition, low-fat content can also be caused by the of a lipid-amylose complex in the production process of raw banana flour (Choo and Aziz, 2010).

The ash content of banana flour noodles with the same consumer acceptance was in the range of $1-2 \%$ and increasing with the addition of raw banana flour (Table 3). This is because of the high levels of minerals, especially potassium and magnesium in bananas (McCance and Widdowson, 2002).

The results showed that the protein content of noodles is higher with the increase of unripe banana flour content. This is not due to high levels of protein in raw banana flour because the protein content of raw banana flour is lower than that of wheat flour. However, according to Choo and Aziz (2010) in the presence of gluten in the mixture, it can lead to significant increases in protein levels. These results are consistent with those obtained by Choo and Aziz (2010) where the levels of noodle protein are increasing with the addition of raw banana flour.

Table 3 shows that the higher of unripe banana flour, the content of dietary fiber in noodles is also increasing. This result is in line with the findings of Choo and Aziz (2010) and Ritthiruangdej et al. (2011). This increase is due to high levels of hemicellulose in bananas. According to Southgate (1976) and VanSoest and Robertson (1977), banana pulp contains hemicellulose compared to other fruits and vegetables.

\subsection{Raw dried noodle cooking qualities supplemented with unripe banana flour}

The raw noodles supplemented with banana flour that have the same acceptance as wheat flour noodles (control) is then analyzed for the cooking characteristics. At cooking, a small portion of starch noodles will separate from the noodles themselves and suspended in cooking water. The noodles will become weaker while the cooking water will be whitish. In quantitative terms, this is called the loss of solids during cooking (SL) (Chen et al., 2003). During cooking, starch noodles will absorb water causing it to expand. This is said to be a developmental capability.

Analysis of cooking on raw banana flour noodles conducted in this research is the water absorption and solids loss during cooking (SL).

\subsection{Water absorption}

Percentage of water absorption states the amount of water that can be absorbed by the noodles. Based on the data in Table 4, it is known that the absorption value of raw noodles with unripe banana flour is increasing with the high content of unripe banana flour in the noodle sample. The value of water absorption is influenced by the protein content in the sample. At the time of the heating process, the gluten protein present in the noodles will denature and form a bond that can prevent water penetration and prevent water from entering the starch granules at the temperature of gelatinization. This will cause the noodle has a strong and chewy texture (Kovacs et al., 2004).

However, as it is known that the protein content of unripe banana flour is much smaller when compared to wheat flour so the possibility of bond formation that will prevent the entry of water into the starch granules becomes less. This is probably what led to the higher content of unripe banana flour noodles in a sample of the percent of water absorption becomes larger.

\subsection{Solids cooking loss (SL)}

Solids loss during cooking (SL) is a measure of the quality of cooking of starch noodles. This is a measurement of starch noodles resistance against disintegration during cooking. The result showed that the value of SL increased with the addition of unripe banana flour (Table 4). According to Vignoux et al. (2005), the value of $\%$ SL associated with bonding between amylose and protein. The weaker the amylose-binding protein (gluten), then the whole structure will weaken and 
facilitate noodles solid material to dissolve during cooking takes place (Rayas Duarte et al., 1996). Table 1 shows that protein content of unripe banana flour is smaller than flour. This probably weakens the bond between amylose and protein that is making it easier to dissolve the solid material during the cooking process.

Table 4. Effect of unripe banana flour content on SL value and water absorption

\begin{tabular}{ccc}
\hline $\begin{array}{c}\text { Unripe banana } \\
\text { flour }(\%)\end{array}$ & $\begin{array}{c}\text { Water absorption } \\
\text { rate }(\%)\end{array}$ & $\begin{array}{c}\text { SL } \\
\text { value }(\%)\end{array}$ \\
\hline 0 & 157 & 4.14 \\
10 & 169 & 5.98 \\
30 & 180 & 8.03 \\
\hline
\end{tabular}

This result in line with the research of Martinez et al. (2009) who reported that partial or complete substitution of durum wheat semolina with fiber material can result in negative changes to pasta quality, including increased cooking loss and Ritthiruangdej et al. (2011).

Noodle products unripe banana flour substitution results demonstrate the value SL below 8\% (Table 4). According to Chinese Agriculture Trade Standard for starch noodles, noodles SL value that is still acceptable is $\leq 10 \%$ (Moorthy, 2002). Noodles with SL high value is undesirable because it would result in a sticky texture of the noodles (Bhattacharya et al., 1999). Based on these data, it can be concluded that the noodle product substitution unripe banana flour that has the same consumer acceptance have SL acceptable value.

\section{Conclusion}

The analysis showed that unripe banana flour contains a water content of $12.91 \%$, fat content $0.46 \%$ (dry basis), ash content $1.02 \%$ (dry basis), protein content $4.45 \%$ (dry basis), carbohydrate content of $81.15 \%$ (dry basis) and dietary fiber amounted to $2.75 \%$ (dry basis). Unripe banana flour produced was then applied as a substituent material in the manufacture of wheat flour noodles. The analysis showed that the noodles contain $10 \%$ and $30 \%$ unripe banana flour have the same admission with the noodle wheat flour.

\section{Conflicts of interest}

The authors declare no conflict of interest.

\section{Acknowledgment}

This study wasfinancially supported by Bina Nusantara Research with contract number 029/VR.RTT/ $\mathrm{V} / 2016$

\section{References}

Badan Pusat Statistik (BPS). (2014). Potret Usaha PertanianIndonesai Sub Sektor. Jakarta: Badan Pusat Statistik

Bhattacharya, M, Zee, S.Y. and Corke, H. (1999). physicochemical properties related to the quality of rice noodles. Cereal Chemistry, 76, 861-867. https:// doi.org/10.1094/CCHEM.1999.76.6.8

Chen, Z., Schols, H.A. and Voragen German Shepherd. (2003). Starch granule size strongly determines processing of starch noodle and noodle quality. Journal of Food Science, 68(5), 1584-1589. https://doi.org/10.1111/j.1365-2621.2003.tb12295.x

Chillo, S., Laverse, J., Falcone, P.M., Protopapa, A. and Del Nobile, M.A. (2008). Influence of the addition of buckwheat flour and durum wheat bran on spaghetti quality. Journal of Cereal Science, 47(2), 144-152. https://doi.org/10.1016/j.jcs.2007.03.004

Choo, C.L. and Aziz, N.A. (2010). Effects of banana flour and b-glucan on the nutritional and sensory evaluation of noodles. Food Chemistry, 119, 34-40. https://doi.org/10.1016/j.foodchem.2009.05.004

Huang Y.-C. and Lai, H.-H. (2010). Noodle quality affected by different cereal starches. Journal of Food Engineering, 97, 135-143. https://doi.org/10.1016/ j.jfoodeng.2009.10.002

Hulme, A.C. (1981). The Biochemistry of Fruits and Their Products. Vol. 2. New York: Academic Press.

Kovacs, M.I.P., Fu, B.X., Woods, S.M. and Khan, K. (2004). Thermal stability of wheat gluten protein: its effect on dough properties and noodle texture. Journal of Cereal Science, 39(1), 9-19. https:// doi.org/10.1016/S0733-5210(03)00058-4

Lestari, S. and Susilawati, P.N. (2015). organoleptic test wet noodles made from taro flour beneng (Xantoshomaundipes) to increase the added value of local food Banten. Proceedings Shem Nas Biodiversity Indonesia, 1(4), 941-946

Maga, J.A. and Kim, C.H. (1989). Co-extrusion of rice flour with dried fruits and fruit juice concentrates. Lebensmittel-Wissenschaft and Technologie, 22, 182-187.

McCance, R.A. and Widdowson, E.M. (2002). The composition of foods. Summary. 6th ed. London: The Royal Society of Chemistry and the Food Standards Agency

Moorthy, S.N. (2002). Physicochemical and functional properties of tropical tuber starches: a review. Starch/Starke, 54(12), 559-592.

Omeire, G.C., Nwosu, J.N., Kabuo, N.O. and Nwosu, M.O. (2015). Cooking properties and sensory evaluation of enriched cassava/wheat 
noodles. International Journal of Innovative Research in Technology and Science, 3(2), 46-50

Ovando-Martinez, M., Sáyago-Ayerdi, S., AgamaAcevedo, E., Goñi, I. and Bello-Pérez, L.A. (2009). Unripe banana flour as an ingredient to increase the undigestible carbohydrates of pasta. Food Chemistry, 113(1), 121-126. https://doi.org/10.1016/ j.foodchem.2008.07.035

Purwandari, U., Khoiri, A., Muchlis, M., Noriandita, B., Zeni, N.F., Lisdayana, N. and Fauziyah, E. (2014). Textural, cooking quality, and sensory evaluation of gluten-free noodle made from breadfruit, konjac, pumpkin or flour. International Food Research Journal, 21(4), 1623-1627

Rayas-Duarte, P, Mock, C.M. and Satterlee, L.D. (1996). Quality of spaghetti containing buckwheat, amaranth, and lupine flours. Cereal Chemistry, 73, 381-387.

Ritthiruangdej, P., Parnbankled, S., Donchedee, S. and Wongsagonsup, R. (2011). Physical, chemical, textural and sensory properties of dried wheat noodles supplemented with unripe banana flour. Kasetsart Journal - (Natural Sciences), 45, 500-509.

Southgate, DAT. (1976). Determination of food carbohydrates. London: Applied Science Publishers.

Sudarmadji. (1997). Procedure Analysis of Food and Agriculture. Yogyakarta, Indonesia: Publisher Liberty.

Tribess, T.B., Hernández-Uribe, J.P., MéndezMontealvo, M.G.C., Menezes, E.W., Bello-Perez, L.A. and Tadini, C.C. (2009). Thermal properties and resistant starch content of green banana flour (Musa cavendishii) produced at different drying conditions. Food Science and Technology - LEB, 42 (5), 1022-1025. https://doi.org/10.1016/ j.lwt.2008.12.017

VanSoest, P.J. and Robertson, J.B. (1977). Analytical problems of fiber. In Carbohydrates and health, $\mathrm{p}$. 69. Westport, CT: Avi Publishing Co.

Widaningrum., Widowati, S. and Soekarto, S.T. (2005). Enrichment soy flour in the manufacture of wet noodles with flour raw material substituted arrowroot flour. Postharvest Journal, 2(1), 41-48.

Widyaningsih, T.B. and Murtini, E.S. (2006). Alternatives to Formaldehyde in Food Products. Retrieved from Pusat Definisi website: http://www.pusat-definisi.com/2012/11/baksoadalah.html.

Winarno, F.G. (1997). Kimia Pangan dan Gizi. Jakarta: Gramedia Pustaka Utama

Winarno, F.G. (2002). Konsumen, Teknologi dan Ilmu Gizi. Jakarta: Gramedia Pustaka Utama
Yadav, B.J., Ritika, B.Y. and Mahesh, K. (2011). Suitability of pigeon pea and rice starches and their blends for noodle making. Food Science and Technology, 44, 1415-1421. https://doi.org/10.1016/ j.lwt.2011.01.004

Zhou, Y., Cao, H., Hou, M., Nirasawa, S., Tatsumi, E., Foster, T.J. and Cheng, Y. (2013). Effect of konjac glucomannan on physical and sensory properties of noodles made from a low-protein wheat flour. Food Research International, 51, 879-885. https:// doi.org/10.1016/j.foodres.2013.02.002 